\title{
DANÇA AFRICANA DE TEFÉ - AM: ORIGEM, FOLCLORE, TRADIÇÃO E RE(SIGNIFICAÇÃO) NO CONTEXTO AMAZÔNICO
}

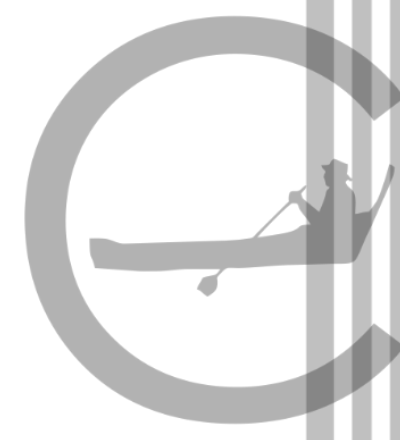

\author{
AFRICAN DANCE OF TEFÉ - AM: ORIGIN, FOLKLORE, \\ TRADITION AND RE(SIGNIFICATION) IN THE AMAZON \\ CONTEXT
}

\author{
Patrícia Torme de Oliveira*
}

\begin{abstract}
Resumo
Na cidade de Tefé - AM, a Dança Africana é considerada uma dança "folclórica" e "tradicional" por ser uma das principais danças a participar do Festival Folclórico de Tefé, e por ser considerada uma das mais antigas deste cenário popular. Contudo, a dança não faz parte apenas de um espetáculo, trata-se também de uma representação da cultura afrobrasileira em um espaço onde as matrizes indígenas e coloniais se sobrepõem. O principal objetivo deste estudo foi compreender as características históricas, origem e o significado para os atores sociais que estão envolvidos de forma direta ou indireta na dança, partindo de suas memórias e narrativas.
\end{abstract}

Palavras-chave: Dança Africana; Folclore; Tefé.

\begin{abstract}
In the city Tefé - AM the African Dance is considered a "folk" and "traditional" dance for one of the main dances to participate in the Folkloric Festival of Tefé, and for being considered one of the oldest in this spectacular scenario. However, dance is not just part of a show, it is also a representation of Afro-Brazilian culture in a space where indigenous and colonial matrices overlap. The main objective of this study was to understand historical characteristics, origin and meaning for the social actors who are directly or indirectly involved in dance, starting from their memories and narratives. The data were collected through interviews with founders, players, ex-players, fans and supporters.
\end{abstract}

Keywords: African Dance; Folklore; Tefé.

\section{INTRODUÇÃO}

\footnotetext{
* Atualmente é aluna do Programa de Pós-Graduação Interdisciplinar em Ciências Humanas da Universidade do Estado do Amazonas. E-mail: patriciacancio@ hotmail.com
} 
No município de Tefé, no estado do Amazonas, ocorre anualmente um dos maiores eventos do Médio Solimões, o Festival Folclórico, ocasião em que inúmeros grupos folclóricos se apresentam após um longo período de preparação e ensaios. Em meia arena ou tablado, contando com a presença de centenas de expectadores, os grupos de danças apresentam e disputam o almejado título, sob a mira atenta dos jurados durante três noites. Todas as danças são organizadas e classificadas para concorrer em categorias específicas, como as "danças populares", "nordestinas", "quadrilhas" e "tribais", porém, a categoria mais importante do evento é de "danças tradicionais", na qual destaca-se a Dança Africana de Tefé-AM.

Esta manifestação de matriz africana faz parte do folclore há quase 40 anos. Em sua configuração para o espetáculo, apresenta três quadros distintos, uma dramatização dos negros no período da escravidão, seguidas de coreografias muito dançantes protagonizadas por Baianos e posteriormente dos Orixás.

O lócus da pesquisa se situou em analisar o processo em que a Dança Africana de Tefé consolidou-se tradicional e folclórica para além do universo do espetacular, e como esta (re)significa a cultura e a presença negra nesta região da Amazônia, ou seja, como uma dança de matriz africana se estabeleceu em um contexto amazônico e como uma representação negra se consolidou em um local onde convém ainda desconstruir a teoria de silenciamento e invisibilidade dos negros.

A pesquisadora Patrícia Melo Sampaio tem se debruçado no estudos das temáticas ligadas a cultura e a presença do negro na Amazônia, principalmente com relação as influências e heranças, sejam elas originárias da condição de escravidão ou não. Neste sentido, a partir de outros estudos já se desmistificou a negação de uma presença negra no Amazonas conforme pesquisas como de Cavalcante ${ }^{1}$ e Abreu $^{2}$. Entretanto, há um indício de dissolução da invisibilidade com relação ao negro em Tefé. Corroborando com os estudos de Sampaio $^{3}$, que apontou criticamente que esta negação tem relação como argumento colonizador que aponta o número reduzido de negros na Amazônia principalmente com relação à economia, ou ainda pela influência do pensamento

\footnotetext{
${ }^{1}$ CAVALCANTI. Ygor Olinto Rocha. "Uma viva e permanente ameaça": resistência, rebeldia, e fugas de escravos no Amazonas Provincial. Dissertação de Mestrado em História, Universidade Federal do Amazonas, UFAM, Manaus, 2013.

2 ABREU, Tenner Inauhiny. "Nascidos no Grêmio da Sociedade": Racialização e mestiçagem entre os trabalhadores na Província do Amazonas (1850-1889). Dissertação de Mestrado do Programa de PósGraduação de Mestrado em História da Universidade Federal do Estado do Amazonas - UFAM, Manaus, 2015.

${ }^{3}$ SAMPAIO, Patrícia Melo. O Fim do silêncio: PresençaNegra na Amazônia. Belém: Editora AÇAÍ/ CNPQ, 2011.
} 
eurocêntrico, onde o negro era classificado no último grau de escala de hierarquia. Nesta região do Médio Solimões as temáticas relacionadas à influência, cultura e presença negra ainda são campo que pouca produção.

Os dados históricos baseados em Cavalcante ${ }^{4}$ apontam que no ano de 1884 existiam 170 escravos negros no município, porém os documentos da época apontam apenas dados quantitativos sem maiores detalhes. Passados mais de um século, de acordo com o IBGE $^{5}$, o último censo de 2010 apontava apenas 2,49\% da população de Tefé se reconhecendo como preta, cerca de 1200 pessoas. Dados primários ainda constatam que atualmente não existem nenhum tipo de movimento negro consolidado no município, a não ser as formas de representação através de grupos de danças.

Esta estudo teve como subsídio a pesquisa documental e a oralidade onde fundadores, brincantes ${ }^{6}$, ex-brincantes e simpatizantes relatam como a Dança Africana de Tefé-AM se originou e se estabeleceu no contexto amazônico tefeense, partindo de suas percepções de criar, apresentar e (re)significar a dança.

De acordo com a análise de fontes escritas e orais, esta dança de matrizes africanas foi criada e fundada na década de 1980, pela comunidade da Escola Estadual Santa Tereza, e para garantir os seus direitos autorais foi registrada como uma associação - Durante a verificação de dados documentais na direção da escola, foram disponibilizados para leitura o registro de associação, as atas de reuniões, e o regimento que estão sob a responsabilidade da gestão e secretaria escolar.

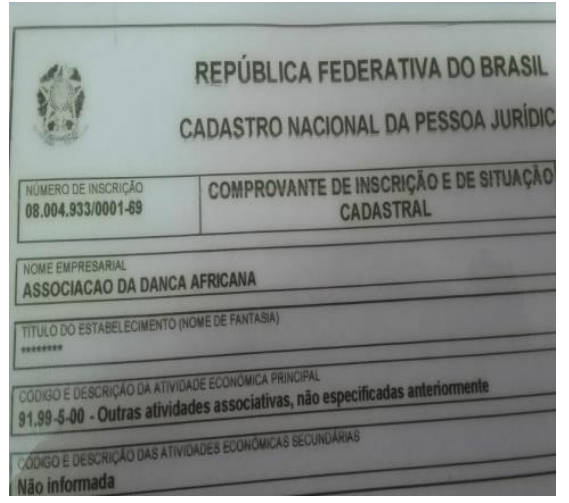

Figura 01: Registro da Associação Fonte: Arquivo da autora.

${ }^{4}$ CAVALCANTI. "Uma viva e permanente ameaça”.

5 De acordo com o último censo realizado pelo Instituito Brasileiro de Geografia e Estatística (IBGE) em 2010 sobre os dados demográficos em Tefé, 79, 78\% se considera pardo, 15,66\% se considera branco, 1,48 se considera indígena e $2,49 \%$ da população se reconhece como preta.

${ }^{6} \mathrm{O}$ termo brincante denomina-se a todo participante das danças folclóricas em Tefé, este termo e categoria serão conceituados e no capítulo 2 deste texto. 
Duas diferentes versões foram relatadas acerca do fato de como a Dança Africana teria se originado. Uma delas sustenta que foi a partir da necessidade de levar algo novo para o Festival Folclórico de Tefé. A outra versão é que ela seria um desdobramento de uma outra dança chamada Gambá ${ }^{7}$, denominação de uma dança típica do estado do Amazonas e Pará, porém em Tefé teria suas peculiaridades, sendo muito popular no município entre os anos de 1960 e 1970, juntamente com outras danças folclóricas da época.

Neste sentido, em cada relato ou narrativa deve haver uma análise de forma única, porque evidentemente a pesquisa não tem pretensão de analisar a fundamentação ou veracidade nos elementos utilizados para compor a apresentação, mas sim utilizar esta memória como uma ferramenta fundamental para preservamos eventos, de forma que através das lembranças individuais seja possível constituir uma memória coletiva, solidificando-se para contar uma história, relacionada a constituição da dança.

Sobre esta questão Portelli afirma:

A memória é um processo individual, que ocorre em um meio social dinâmico, valendo-se de instrumentos socialmente criados e compartilhados. Em vista disso as recordações podem ser semelhantes, contraditórias ou sobrepostas. Porém, em hipótese alguma, as lembranças de duas pessoas são - assim como as impressões digitais, ou, a bem da verdade, como as vozes - exatamente iguais ${ }^{8}$.

\section{A APRESENTAÇÃO NO ESPETÁCULO! A DANÇA AFRICANA CHEGOU!}

"Africana chegou, ôôo

Africana é emoçãoôôo

Africana é showôôô Ela é tradição"

A Dança Africana de Tefé -AM, em sua composição para o espetáculo, conta com mais de 100 brincantes, divididos em três quadros, são eles: "Negros", Baianos e Orixás. Neste contexto também existem alguns destaques que são itens obrigatórios, que concorrem ao Festival Folclórico, como o apresentador, a porta-estardante e a rainha, e

\footnotetext{
7 Também denomina o nome do instrumento de marcação feito com tronco de árvore, é uma dança de terreiro, constituída por brincantes, um marcador, cantores, uma mulher solista e seu parceiro. (FRADE, 1997)

${ }^{8}$ PORTELLI, Alessandro. Forma e significado na História Oral. A pesquisa como um experimento em igualdade. Projeto História. N, 14, SP. PUC/SP, fevereiro/1997. p.16.

${ }^{9}$ Música de chamada da Dança Africana de Tefé, criada especialmente para o início da apresentação, por uma das fundadoras, conhecida popularmente por D. Dulcina.
} 
outras figuras remanescentes do folclore como a "mãe Xandoca" que representa a mãe de todos os escravos, e era um personagem do antigo cordão folclórico "Gambá".

Para além desses destaques, há outros brincantes que fazem parte da banda, composta por aproximadamente 20 integrantes, onde tocam os seguintes instrumentos de percussão: Atabaques, Tambores, Afoxés, Agogôs, Tarol, Xequerês e Espanta-cão (cruz de madeira, com platinelas nos braços e por um reco feito de molas). Além do cantor principal que concorre ao item melhor cantor, tem mais duas ou três pessoas que fazem o apoio de voz.

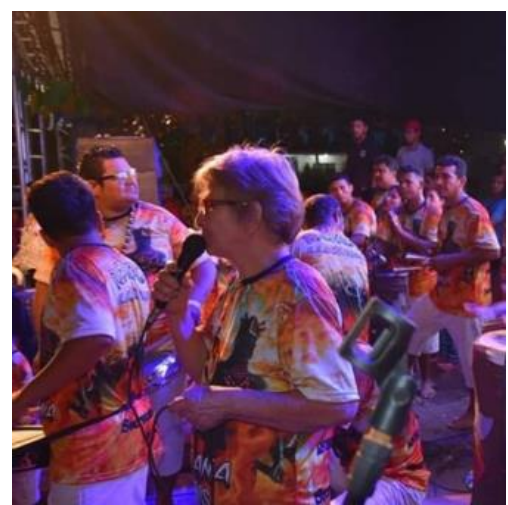

Imagem 01: Banda Africana

Fonte: Taline Ramos Marinho

As músicas seguem um repertório de acordo com cada momento ou quadro. A entrada da dança inicia com a apresentação da porta estandarte, cuja música é embalada pelo Canto das Três Raças ${ }^{10}$. Posteriormente inicia-se o primeiro quadro protagonizado pelos personagens dos "negros", que dramatizam cenas de tortura e sofrimento sob os castigos e chicote do personagem do feitor, remetendo ao período da escravidão. Este quadro é embalado apenas ao som de um poema de lamento conhecido como "Banzo Negro".

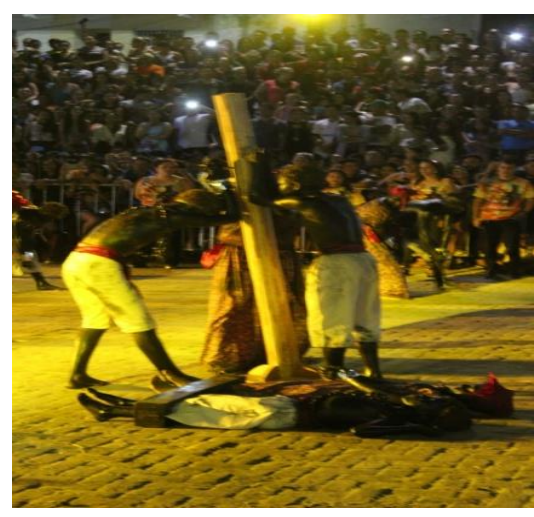

Figura 02: Cenas da Escravidão Fonte: Taline Ramos Marinho

\footnotetext{
${ }^{10}$ Música Canto das Três Raças de autoria de Paulo César Pinheiro e Mauro Duarte, interpretada pela
} cantora Clara Nunes, no álbum de mesma denominação da gravadora EMI-Odeon lançado no ano de 1976. 
Após esta cena dramática a personagem de Princesa Isabel adentra ao espaço do espetáculo para assinar a lei áurea ${ }^{11}$. A partir deste momento a música e a dança dominam o palco e todos personagens se colocam a dançar, e vão abrindo espaço para a parte mais dançante do espetáculo, iniciando-se o segundo quadro, em que são anunciados os Baianos.

$\mathrm{Na}$ Dança Africana de Tefé os Baianos fazem parte do "cordão folclórico", ou seja, o grupo que puxa toda ação do dançar, e sua formação é constituída por aproximadamente 20 a 25 casais. Na visão dos organizadores e até mesmo dos próprios Baianos, 20 casais são o quantitativo ideal para que haja um grande espetáculo, pois, logo após a dramatização do quadro dos "Negros", é que inicia-se o segundo quadro da Dança Africana, em que a cênica de dramatização é substituída pela cênica dançante, e com uma entrada muito entusiasmada, Baianos e Baianas passam a orquestrar todo o espetáculo dando giros e fazendo movimentos dinâmicos, ocupando por completo o espaço do palco. As músicas dos Baianos são alegres e algumas também são herdadas do cordão folclórico do Gambá.

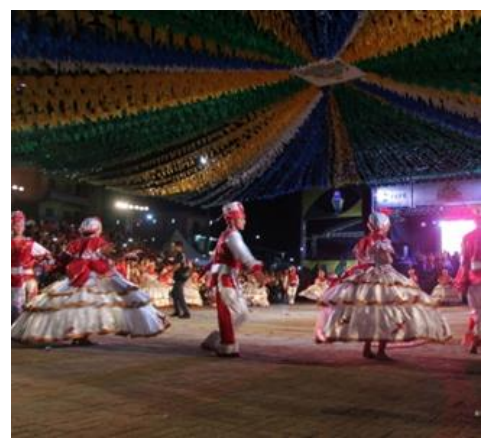

Figura 03: Quadro de Baianos Fonte: Taline Ramos Marinho

Os Baianos executam e apresentam aproximadamente 40 coreografias diferentes, pois também fazem parte de todo o terceiro quadro, onde suas coreografias representam o culto e a homenagem aos Orixás. Tais coreografias foram criadas há muitos anos. O casal puxador dos Baianos, os brincantes Sônia e Norberto, relataram não lembrar o ano que cada coreografia foi elaborada e inserida, mas destacaram que muitas das coreografias foram criadas em conjunto entre eles e professores da escola, e que sempre foram montadas durante o ensaio com todos os Baianos e Orixás. Destacaram que nunca teve

\footnotetext{
${ }^{11}$ Hoje é possível ter uma visão mais critica desse processo, mas naquele momento histórico de construção da dança, o objetivo era educar mostrando todo sofrimento e opressão representado pela escravidão.
} 
uma coreografia previa, ou seja, nunca levaram coreografias prontas para os ensaios, que em todos os casos, a criatividade e elaboração surgiu na coletividade.

O terceiro quadro da Dança Africana de Tefé é o dos Orixás, totalizando 12 destaques. Onze representam Orixás do Camdomblé, e um trata-se de uma entidade de umbanda. Durante a apresentação de cada destaque a banda executa pontos ${ }^{12}$ religiosos, onde os Baianos executam coreografias que tem movimentos e significados relacionados a representação de cada destaque.

Para cada destaque, que adentra o espaço de apresentação é realizada uma chamada de ponto de partida. No histórico “oficial” de apresentação da dança, há uma descrição sobre representação, sincretismo e as simbologias de cada Orixá, que é sempre anunciada pelo apresentador antes de iniciar a parte dançante.

OXALÁ- Maior dos santos dos terreiros da Bahia, Senhor do Bom fim, pai de todos os Orixás, sua cor é o branco, seu símbolo é o cajado, no sincretismo religioso é Jesus Cristo, Baianas e Baianos saúdam OXALÁ- ÈPA BÀBÁ. XANGÔ é o Orixá da Justiça, deus do trovão, sua cor é vermelha, seu elemento é o fogo, tem como símbolo o machado e no catolicismo é São Jerônimo, Baianos e Baianas recebam XANGÔ- KAÔ KABECILÊ MEU PAI!IANSÃ é a senhora dos ventos e das tempestades, esposa predileta de Xangô, seu elemento é o fogo e sua cor o vermelho, seu símbolo é o chicote, no catolicismo é Santa Bárbara, Baianos e Baianas recebam IANSÃ-EPAREY OYÁ!OGUM OU OGUM MEGÊ Orixá guerreiro, é o senhor da guerra, sua cor é o azul, e seu símbolo é a espada, no sincretismo religioso é São Jorge guerreiro! Baianos e Baianas saúdam OGUMOGUM YÊ MEU PAI! OXÓSSI o caçador, é o senhor das matas e do conhecimento, seu símbolo é o arco e flecha, no sincretismo religioso corresponde a São Sebastião, Baianos recebam OXÓSSI-OKÊ ARÔ! OXUM senhora das águas doces e das cachoeiras, sua cor é o amarelo, e seu símbolo o espelho, deusa da fertilidade e vaidade, no sincretismo equivale a Nossa Senhora da Conceição. Baianos recebam MAMÃE OXUM- ORA YÊ IÊ, Ô! NANÃ OU NANÃ BURUKÊ senhora da lama e das águas paradas, é a mais velha das Orixás, sua cor é o roxo, seu símbolo o Ibiri, no sincretismo religioso é Santa Ana, Baianas e Baianos recebam NANÃ BURKÊE-SALUBÁ. OBÁ, Orixá guerreira e senhora dos amores impossíveis, terceira esposa de Xangô, seu símbolo é o escudo e a lança, no sincretismo é Santa Catarina, Baianos e Baianas recebam OBÁ- AKIRÔ OBÁ YÊ! OXUMARÉ é o Orixá da abundância, na água assume o aspecto feminino na terra o aspecto masculino, suas cores são do arco-íris, e seu símbolos o arco-íris e a cobra de ferro, no sincretismo corresponde a São Bartolomeu. Baianas e Baianos salvem OXUMARÉ- ARROBOBOI, MEU PAI! OMULÚ OU OBALUAIÊ é o Orixá das doenças contagiosas, mas também da cura, foi abandonado por Nanã e criado por Iemanjá, no catolicismo corresponde a São Roque, Baianos recebam OMULÚ OU

\footnotetext{
12 Os pontos de Candomblé ou Umbanda são os cânticos sagrados dessas religiões afro-brasileiras que têm diversas funções como, por exemplo, homenagear uma entidade ou convidá-la ao convívio do centro, na Dança Africana de Tefé estes pontos são utilizados para a apresentação.
} 
OBALUAIÊ-ATOTÔ MEU PAI! IEMANJÁ é a senhora das águas, mãe de todos os Orixás, chamada também de Janaína a sereia do mar, sua cor é o azul, seu símbolo é o espelho e no sincretismo religioso representa Nossa Senhora. Baianos e Baianas recebam Janaína a sereia do mar IEMANJÁ-ODOYÁ! ADOCIYABA.

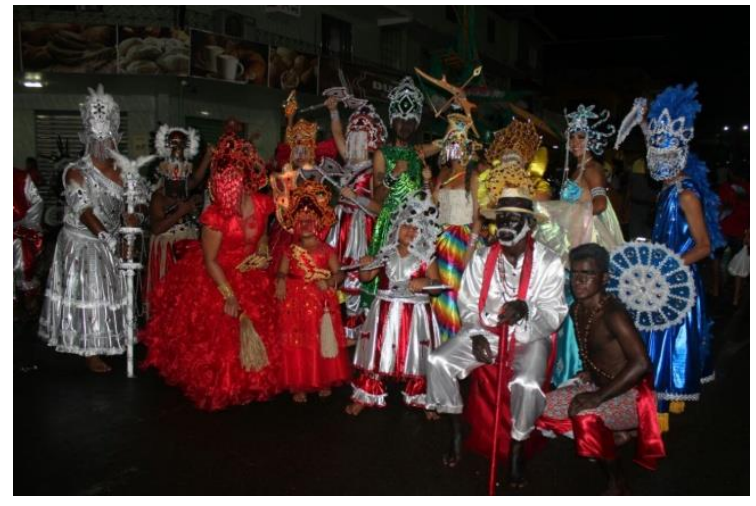

Figura 04: Orixás - Destaques

Fonte: Taline Ramos Marinho

\section{O SURGIMENTO EM HOMENAGEM AO NEGRO}

Na busca pela compreensão de como a Dança Africana de Tefé foi originada ou criada, alguns colaboradores da pesquisa durante as entrevistas, sugeriram a procura pelo único livro que contém uma narrativa da dança, o livro do escritor/memorialista tefeense Augusto Cabrolié.

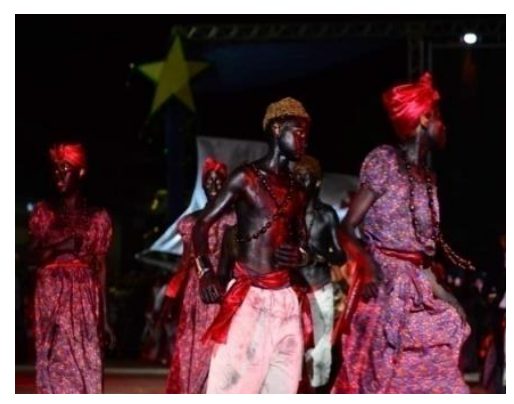

Imagem 01: "Negrinhos" quadro da Escravidão, Festival 2018.

Fonte: Orange Cavalcante.

Após conseguir localizar um exemplar, constatou-se de fato informações históricas sobre o folclore e a cultura do município com suas lendas lendas e informações sobre as danças típicas da época. Algumas das danças mencionadas já encontram-se extintas, outras ainda em atividade, como a Dança Africana de Tefé. No livro Tefé e a cultura 
Amazônica" de 1996, o professor Augusto Cabriolié narra os aspectos mais importantes da Dança Africana:

Esta dança foi criada e organizada pelos professores da Escola Estadual Santa Teresa, procurando levar algo de novo para o Festival Folclórico de Tefé. Foram aproveitadas todas as opiniões, selecionados os discos, pesquisado no centro de Umbanda e, montada de acordo com tudo o que se sabe da cultura negra e dos ritos afro-brasileiros. Os personagens pintados de negros, trajando estampas, saias rodadas, os argolões e o cajado de Oxalá para dar força e energia, vêm com os rituais, danças, magia e divindades africanas ${ }^{13}$.

Na versão do autor, ele ressalta que a Dança Africana foi elaborada e criada pelos professores da Escola Estadual Santa Tereza, no sentido de levar uma nova proposta para concorrer no Festival Folclórico, e que uma das principais fontes de pesquisa e informações foi um centro de umbanda do município. De acordo com Augusto Cabrolié, a intenção era elaborar a dança conforme os rituais religiosos afro-brasileiros e a cultura negra. Ainda coloca que para homenagear ao negro e sua religiosidade, os personagens representando negros escravizados tinham seus corpos pintados, uma prática que inclusive permanece até hoje $\mathrm{e}^{14}$.

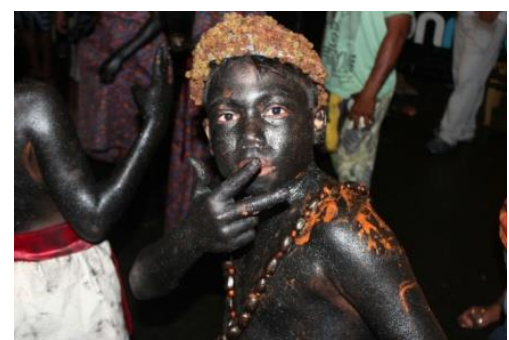

Imagem 03: "negrinho" no festival de 2018

Fonte: Taline Ramos Marinho

Para as principais fundadoras da Dança Africana, D. Dulcina e D. Dora a mistura com carvão e óleo, seria uma forma mais fiel de representação do negro, pois destacaram que este aspecto teria uma ligação direta ao que consideram como folclórico, bem como tradicional no contexto da dança e do Festival Folclórico de Tefé.

Seguindo no texto de Cabrolié, o autor destaca os seguintes elementos que compõe a Dança Africana durante a apresentação. São eles:

${ }^{13}$ CABROLIÉ, Augusto. Tefé e a cultura amazônica. Juiz de Fora: Editora Instituto Paulo Freire, 1994, p.62.

${ }_{14}$ À época não se tinha a ideia de que a chamada "black face" fosse uma prática racista. Os professores a faziam pra trazer maior realismo para apresentação. 
a) Princesa Isabel, depois de muitas leis assinadas em favor aos escravos, assinou a lei Áurea .b) Capoeira, utilizada pelos negros como arma de defesa e na segurança política. c) Os Baianos, um pedaço da África se mudaram para o Brasil com os escravos, e é na Bahia que até hoje sentimos a força da cultura negra, através dos pratos típicos e das cerimônias religiosas. Negrinhos e Baianos, dançam e cantam ao som da batucada, homenageando seus Orixás que se apresentam, vestidos de modo especial com um canto e dança. São Homenageados: a) Oxalá, maior dos santos dos terreiros da Bahia, Senhor do Bom Fim, pai de todos os Orixás. b) Iansã, senhora dos ventos e das tempestades, guerreira valente, terceira esposa de Xangô. c) Oxóssi, deus da caça, das florestas, seu símbolo é o arco e a flecha e usa chapéu de couro.d) Xangô, deus das trovoadas, raios, chuvas e tempestades. Suas cores são o vermelho e o branco, usa o machado como símbolo. e) Ogum, deus da guerra e da luta, seu símbolo é espada e a lança. f) Preto Velho, negro sofrido que morreu durante a escravidão. g) Iemanjá, figura amada e tida como esposa mulher e mãe de todos, relacionada com Maria, Janaína, a sereia, a Rainha do Mar, a senhora das águas, é a esposa de Oxalá, mãe de todos os Orixás. Seus adeptos costumam reunir-se nas praias lançando às águas, flores, moedas, champagne, velas e outros presentes ${ }^{15}$.

$\mathrm{O}$ autor ressalta as figuras de Princesa Isabel, da Capoeira e de Baianos e "Negrinhos" que na dança homenageiam aqueles que representam dentro da religiosidade a resistência negra, através do culto aos Orixás do Candomblé, e de uma entidade de umbanda que é o Preto Velho.

Além destes Orixás, outros foram incorporados no decorrer dos tempos, como Oxumaré, que representa a cobra arco-íris e tem a dualidade do feminino e masculino. Omolú ou Obaluaiê, que é o Orixá das doenças e da renovação dos espíritos. Obá, que é a orixá guerreira e a primeira esposa de Xangô, e o Orixá mais recentemente incorporado no quadro de divindades da Dança Africana de Tefé foi Nanã Burukê, que é a mais velha do panteão dos demais Orixás, considerada a senhora do barro, mangues e pântanos.

Para os brincantes e alguns fundadores, a pessoa que tem propriedade para relatar sobre a criação da Dança Africana de Tefé, é D. Dulcina, professora já aposentada da Escola Estadual Santa Tereza e uma das fundadoras da dança. Ela mora na frente da quadra onde os ensaios e reuniões são realizadas. D. Dulcina ainda tem na dança algumas influências e sua opinião e decisão são sempre levadas em consideração, por todos os brincantes da Dança Africana. Além de praticamente idealizar a dança, juntamente com os demais professores da época, ela foi fundamental em vários aspectos como: organizar entradas, coreografias, selecionar destaques, compor músicas inéditas, bem como ser a

${ }^{15}$ CABROLIÉ, 1996, PP 62-63. 
principal cantora a puxar a banda da dança por vários anos. Em seu breve relato D. Dulcina descreve como foi o surgimento da Dança Africana:

A Dança Africana surgiu no município de Tefé em 1981. O objetivo de criar a dança foi valorizar e divulgar a cultura africana e afro-brasileira mostrando um pouco do que herdamos do negro através da apresentação dos Orixás, da batucada, instrumentos musicais, cantos, indumentária, enfeites e adereços e o gingado. A Africana veio para enriquecer o folclore tefeense $\mathrm{e}^{16}$.

Outro relato muito importante relacionado à criação e permanência da Dança Africana no cenário do folclore tefeense, foi de D. Dora Ramos Marinho, professora também já aposentada da Escola Estadual Santa Tereza, que reside a apenas alguns metros de distância da instituição. Casada com o historiador tefeense José Lino do Nascimento Marinho, D. Dora além de co-fundadora também cantava ao lado de D. Dulcina e contribuiu em todo processo de criação da dança. Sua família se formou e cresceu convivendo com a Dança Africana e todos participaram desde criança. Atualmente duas de suas filhas e um neto continuam participando como brincantes e difusores. Uma como Orixá, outra como cantora principal e o neto como instrumentista de percussão na banda. Seu relato também esclarece como foi o início da Dança Africana:

Quando colocaram a "Africana" nossa referência foi esta época em que o negro escravizado vem para o Brasil, chegando pelo nordeste, principalmente na Bahia [...] a primeira versão era mesmo só a dança com negrinhos e Baianos, em 82 é que veio o primeiro Orixá que foi Iemanjá...que se não me engano era a Romilda. A dramatização com Princesa Isabel e os outros Orixás foram sendo incorporados depois com o tempo [...] e logo nos primeiros anos só era aquela dança negra mesmo, somente com a marcação do passo, quem era de família de negros ainda tinha mais evolução, mas quem não era ficava só na marcação ${ }^{17}$.

Neste trecho do relato de D. Dora ela esclarece que primeiramente a dança foi composta por negrinhos e Baianos e somente no ano seguinte, em 1981, o primeiro Orixá foi inserido. Importante destacar que D. Dora menciona sobre a participação de pessoas pertencentes a famílias negras, e que estes destacavam-se na dança. Ainda assim pintavam-se de óleo. E segue seu relato mencionando sobre as pesquisas realizadas na época para implementar ainda mais elementos na dança:

\footnotetext{
${ }^{16}$ Entrevista realizada com D. Dulcina em março de 2019.

${ }^{17}$ Entrevista realizada com D. Dora Marinho em outubro de 2018.
} 
Aí depois quando criaram mesmo um amor pela "Africana", é que...tínhamos muitos professores bons naquela época, e aí tinha uma professora chamada Auxiliadora Reto, Dorinha, ela é uma pessoa muito inteligente, de muita cultura, junto com a D. Dulcina que também é muito inteligente, aliás D. Dulcina foi fundamental, esta dança só está de pé até hoje pelo esforço dela... aí elas pensaram "Mas não pode ficar somente nisto" e elas pesquisaram! Naquela época não tinha internet, mas elas foram atrás e pensaram, leram muito sobre isto... e aí ela foi evoluída desta maneira, os professores se empenharam muito, naquela época os professores se empenharam muito ${ }^{18}$.

O professor F. Torres, um brincante antigo da dança, esclarece que, primeiramente, foi denominada "Dança Africana professores e alunos na Roça". Esta denominação foi provavelmente simplificada, permanecendo somente Dança Africana, alguns se referem ainda somente como "Africana":

A Dança Africana, surgiu no ano de $1982^{19}$, com intuito de abraçar a causa negra. Em um primeiro momento a dança se chamou "Dança Africana professores e alunos na Roça", [...] então neste momento tinha a necessidade de a escola criar uma dança inovadora para o Festival Folclórico. O primeiro momento foi visitar um centro de umbanda, que nós temos aqui em Tefé, localizado no bairro do Abial, que é coordenado pelo senhor Raimundo Paes, uma pessoa que orientou muito bem no sentido de homenagear a cultura negra ${ }^{20}$.

A elaboração da Dança como já foi mencionado, também teve a orientação do centro de umbanda, na figura do seu Raimundo Batuqueiro ${ }^{21}$. Corroborando com esta afirmação, o apresentador F. Torres aponta que essa contribuição se deu especialmente para a "Dança dos Baianos", que foi elaborada a partir dos elementos da religião afrobrasileira. Sobre o aspecto da religião o apresentador F. Torres menciona:

A princípio tinha todo um ritual que as pessoas [...] tinham um intuito de que seria uma dança de macumba e tudo mais, a nossa dança em si, realmente ela é um Candomblé, mas ela homenageia a cultura negra, porque no período da escravidão, nós somos sabedores que historicamente o negro era proibido de entrar na religião católica, então eles se refugiavam formando quilombo e assim exaltavam os Deuses da

\footnotetext{
${ }^{18}$ Entrevista realizada com D. Dora Marinho em outubro de 2018.

${ }^{19}$ Nos relatos dos entrevistados, houve divergências quanto ao ano de fundação da Dança Africana de Tefé, alguns afirmaram ter sido em 1981 e outros 1982. O histórico aponta 1981, porém estas divergências são naturais, visto que todo o relato sobre qualquer evento é subjetivo, e que em uma pesquisa não existem verdades absolutas, quando se trabalha com memória e história.

${ }^{20}$ Entrevista realizada com F. Torres em abril de 2019.

${ }^{21}$ Raimundo Paes Nazareno, mais conhecido como "Raimundo Batuqueiro", é um respeitado senhor tefeense de 70 anos, é Pai de Santo do Centro de Umbanda de Tefé que se tem registro, (existem outras casas, porém de outras falanges, denominadas de quimbanda) sua casa é muito conhecida por organizar festejos como de São Sebastião, São Jorge dentre outros, além de realizar muitas ações caridosas naquele local, em prol dos mais necessitados. Também é parteiro tradicional e afirma realizar a prática do partejar através dos Guias espirituais vovó Maria Gonga, uma escrava que fazia partos da senzala, e a Caboca Mariana uma enfermeira. Ambas o auxiliaram em seu primeiro parto, em uma situação de extrema emergência.
} 
sua religião através da religião católica, como Iemanjá, que é representada por Nossa Senhora de Fátima. ${ }^{22}$

$\mathrm{Na}$ fala de F. Torres, ele evidencia a questão do sincretismo religioso, e como ocorreu na história, a questão foi uma forma dos negros escravizados exaltarem seus próprios deuses, só que através dos santos católicos. Como a dança teve também como campo de pesquisa um centro de umbanda $^{23}$, religião que foi criada a partir do sincretismo, consequentemente houve influência na dança.

Na Dança Africana cada Orixá apresentado tem uma narrativa veiculada a seu simbolismo e seu significado na religião do Candomblé. Entretanto, como muitas referências foram obtidas na religião de umbanda, o sincretismo se faz presente nesta apresentação através da equivalência de cada Orixá na religião católica, e apesar de serem de matrizes africanas, o candomblé e a umbanda são religiões totalmente diferenciadas.

Com relação às várias versões de criação da Dança Africana de Tefé, a ex-gestora da Escola Estadual Santa Tereza, Shirlei Rocha, afirma que foi praticamente uma espécie de continuação do Gambá. Porém, sob uma nova ótica, que implementou outros elementos, representando de forma mais marcante a cultura negra. Para Shirley Rocha:

A Dança Africana de Tefé, surgiu em 1981 na união e vontade do corpo docente da Escola Santa Tereza, principalmente para participar do Festival Folclórico, porém o grande estímulo veio a partir do cordão folclórico "O Gambá", que já estava se perdendo. Então resolveu-se criar uma outra dança também voltada para a cultura negra ${ }^{24}$.

Na narrativa realizada por Cabrolié (1996) sobre a Dança do Gambá, existem alguns elementos do cordão folclórico mais antigo, que atualmente compõe a Dança Africana, e na fala da ex-gestora, justamente a outra versão seria uma forma de continuação do antigo cordão folclórico, como Iemanjá e Iansã, que ele designa como divindades, Preto Velho e uma figura denominada "Mãe Xandoca" que representa a mãe de todos os negros.

Assim, o autor discorre sobre a dança:

O Gambá é uma dança de ritmo afro-brasileiro, que na nossa região, era dançada na festa de São Benedito, comemorada no dia 6 de janeiro, Dia de Reis, e cujo nome vulgar era festa do "Santo Preto". Durava dois dias e duas noites inteiras, o cavalheiro numa dança especial, tirava a dama para dançar, embora dançassem soltos. Todos dançavam,

\footnotetext{
22 Entrevista realizada com F. Torres em abril de 2019.

23 A Umbanda representa a corrente mais "brasileira" do complexo afro religioso, pois trata-se de uma religião criada no Brasil a partir do sincretismo de suas principais ontologias religiosas: a cristã e a africana. Seus rituais são realizados em língua portuguesa/brasileira e as entidades veneradas são sobretudo, os "caboclos" (índios), "pretos-velhos" e "curumins" (crianças), além das "falanges africanas". (Corrêa, 1994)

${ }^{24}$ Entrevista realizada com Shirlei Rocha em março de 2019.
} 
homens, mulheres, idosos e crianças. Nesta festa eram muitos batuqueiros que batiam o "Gambá" (tambor grande feito de madeira de lei), acompanhado por reco-reco, um pandeiro e mais dois tambores pequenos. As pessoas idosas, cantavam seus versos sempre em homenagem ao santo e aos pretos, inventados na hora, como no "repente" ou no "improviso". Cada parte cantada e tocada tinha um significado como "Cauã", pássaro de magia cantada para a afastar o mal, "São Caetano" (o santo da machadinha), era cantada de madrugada para homenagear o dia, Iemanjá (deusa da água), que salva os pretos em dia de tempestade. Havia homenagem aos escravos através de "Mãe Xandoca" e "Preto Velho", e divindades como Iansã, e de culto a seres ou fenômenos da natureza, como a maresia, o açaí, o cajueiro. Finalmente misturavam-se tais entidades religiosas com os santos (Santo Antônio, São Pedro, São João e São Marçal) num verdadeiro sincretismo folclórico-religioso. Em Tefé, se dançava muito o Gambá que, mais tarde, veio a aparecer no Festival Folclórico apresentado pelo famoso artista tefeense Ambrósio Ramos ${ }^{25}$.

A ex-brincante do antigo cordão folclórico do Gambá, D. Auxiliadora Lima de Souza, também relembra como era esta dança folclórica, e relata sobre o ritmo que para ela ficou marcada em sua memória:

Eu não lembro bem o ano que eu dancei o "Gambá", mas eu lembro que um grupo saiu do Frei André e foi para o Santa Tereza, lá pelos anos 70, e lá havia uma professora chamada Dadá, o "Gambá” também era do Santa Tereza, só que naquela época ainda não havia a parte da religiosidade, eram apenas os escravos e o batuque. Essa é a lembrança que eu tenho, eu não lembro bem o contexto dos brincantes, mas não havia os Baianos, era totalmente diferente da Dança Africana apresentada agora [...] lembro que os brincantes cantavam com garra e tinha uma música assim: "Ajuntai, ajuntai, ajuntai açaí pelo chão" [...] Na verdade o Gambá acabou mas não acabou em mim, porque quando eu viajei para a Bahia eu me lembrei muito do Gambá, pelo ritmo dos batuques de lá $^{26}$.

No trecho da entrevista de D. Auxiliadora Lima de Souza, há reafirmação sobre o cordão folclórico do Gambá também pertencer a escola Santa Tereza, porém, coloca que não havia uma ligação com religiosidade, mas já havia a representação do negro escravizado e o batuque, em sua percepção não há similaridade com a dança apresentada hoje, mas fala sobre a semelhança com o batuque e o ritmo da Bahia.

É perceptível nas falas dos entrevistados os objetivos com relação à criação da Dança Africana -muito embora sua origem não esteja atrelado a um grupo relacionado as questões identitárias dos negros - já que foram concebidos em um ambiente educacional, no sentido de acolher e homenagear a causa negra, tanto na valorização quanto na

\footnotetext{
${ }^{25}$ CABROLIÊ, 1997, P.31.

${ }^{26}$ Entrevista realizada com D. Auxiliadora Lima de Souza em outubro de 2019.
} 
divulgação da cultura afro-brasileira. Outro elemento que contribuiu para a criação foi a necessidade de a escola apresentar algo inovador para o Festival Folclórico do município.

O fato de precisar a data de origem ou fundação da Dança Africana de Tefé, não foi possível, porém, ao verificarmos os relatos, chegar a apenas uma versão e reconstituir uma história sem brechas, mas que tornasse referência, ou ponto de partida para um aprofundamento maior na história da dança e sua relação com esta comunidade, além de se tornar uma memória impressa no folclore da região. Como a exemplo da denominação da Dança Africana, que no caso nenhum dos entrevistados conseguiu lembrar com precisão, entretanto, no trecho da entrevista do professor F. Torres pode haver uma pista para a escolha do nome da Dança:

Depois exaltamos o negro como um pedaço da África que veio para o Brasil, onde Salvador era o centro de tudo, o refúgio de tudo do período da venda dos escravos e assim lá predominou-se o maior número de baianos ${ }^{27}$.

\section{DANÇA AFRICANA: "TRADICIONAL" E "FOLCLÓRICA"}

Fazem parte do Festival Folclórico de Tefé as categorias de "quadrilhas", “danças nordestinas", "carimbós”, “danças tribais” e "bois-bumbás”, mais conhecidas do folclore popular. Outras manifestações são originárias da própria região, como a Ciranda, O Barqueiro, Dança Afro-América, Cunhã Poranga e a Dança Africana, tema deste estudo, e que estão categorizadas como "danças tradicionais". As danças do Tangará, Dança Cigana, Ganga Zumbá ${ }^{28}$, Caninha Verde, Pastorinhas, Dança Gambá e muitas outras se perderam no tempo e deixaram de ser apresentadas, ficando apenas registros bibliográficos ou nas memórias tefeenses, e que talvez algum momento podem ser resgatadas como aconteceu no caso da Ciranda que voltou no ano de 2019.

Em uma das definições para Danças Folclóricas, Frade ${ }^{29}$ coloca que o termo se configura como expressões populares, desenvolvidas em conjunto ou individualmente, que tem em suas composições coreográficas um elemento definidor, e historicamente se originaram a partir de elementos integrantes de rituais religiosos, guerreiros ou fúnebres dos chamados "povos primitivos". Dos movimentos originais juntaram-se a outros e

\footnotetext{
${ }^{27}$ Entrevista realizada com F. Torres em 30 de abril de 2019.

28 A Dança Ganga Zumbá foi criada especialmente para disputar com a Dança Africana no Festival Folclórico de Tefé, foi uma criação de uma ex-gestora da Escola Estadual Santa Tereza, porém, durou pouco tempo e logo se dissolveu, ficando apenas registrada na memória dos tefeenses. (Fonte: Dora Marinho, outubro de 2018)

${ }^{29}$ FRADE, Cássia. Folclore $2^{a}$ edição. São Paulo: Global 1997, P. 36.
} 
foram se transformando e tornando-se complexos, partindo de simples marcações rítmicas a arte autônoma, liberta e em contínua criação ${ }^{30}$.

Em Tefé, cada grupo de danças ou manifestação artística foi primeiro criado e elaborado para depois passarem a fazer parte do Festival Folclórico. Algumas danças já fazem parte de uma cultura popular ou são originárias de uma região específica, como as quadrilhas, cangaços, carimbós, Bois-bumbás e as tribais, portanto, fica claro sua classificação e categoria, por naturalmente já pertencerem ao folclore. Já nas danças da categoria "Folclóricas Tradicionais", se faz indispensável compreender a definição e esta relação, no pensamento dos moradores de Tefé, já que se trata de um status local.

A Dança Africana de Tefé, mesmo que baseada ou inspirada em matrizes africanas, está inserida em tal contexto local, uma vez que teve como propósito principal de criação, de acordo com os relatos das fundadoras, a participação no Festival Folclórico. Portanto, eis a importância de trazer luz à compreensão acerca de folclore, tradição e brincantes neste contexto, já que estes termos estão sempre presentes nos discursos do senso comum e se tornam substanciais para o campo de estudos, tornando-se pertinente compreendêlos, para inclusive conseguir relativizá-los com o estudo sobre a (re) significação da dança. Na carta brasileira sobre folclore destaca-se:

\begin{abstract}
Folclore é o conjunto das criações culturais de uma comunidade, baseado nas suas tradições expressas individualmente ou coletivamente, representativo de sua identidade social. Constituem-se fatores de identificação da manifestação folclórica: aceitação coletiva, tradicionalidade, dinamicidade, funcionalidade. Ressaltamos que entendemos folclore e cultura popular como equivalentes, em sintonia com o que preconiza a Unesco. A expressão cultura popular manter-seá no singular, embora entendendo-se que existem tantas culturas quantos sejam os grupos que as produzem em contextos naturais e econômicos específicos ${ }^{31}$.
\end{abstract}

A dinamicidade do folclore é apontada por Doralice Alcoforado ${ }^{32}$ (2008) quando disserta que "o folclore é dinâmico e evolui com as mudanças da sociedade. Não é sobrevivência, mas cultura viva". Com isso as manifestações folclóricas seriam provenientes do povo brasileiro ou foram (re)inventadas tomando como base outras culturas, para então incorporá-las às suas tradições.

\footnotetext{
${ }^{30}$ FRADE, Cássia. Folclore $2^{\text {a }}$ edição. São Paulo: Global 1997, P. 36.

${ }^{31}$ CARTA DO FOLCLORE BRASILEIRO, 1995.

32 ALCOFORADO, Doralice. Do Folclore à Cultura Popular. In: Boitatá: revista do GT de Literatura Oral e Popular da ANPOLL.Londrina/Paraná. Número especial de agosto à dezembro de 2008.
} 
Desta forma, esta categoria dentro do cenário tefeense acolhe ou até mesmo "aceita" os mais variados estilos e tipos de danças, sejam elas provenientes da cultura popular, de raízes regionais, de outros povos e países, ou ainda, que são (re)criadas, mantendo-se em constante dinamicidade. Da mesma forma que o termo "tradicional" ou "tradição" é comumente utilizado para qualificar ou categorizar algumas danças que fazem parte do cenário cultural de Tefé, principalmente a Dança Africana, que tem cada vez mais incorporado o termo em seus históricos e suas apresentações.

Hobsbawm ${ }^{33}$, destaca que está na 'tradição inventada' compreender o conjunto de práticas, geralmente reguladas por regras implícitas ou explicitamente aceitas. Tais práticas, podem ser tanto de natureza ritual como simbólica, e se propõem a assinalar valores e normas determinados de comportamento por meio da repetição, o que leva naturalmente a uma continuidade em relação ao passado. Entretanto, conforme há alusão a um passado histórico, as tradições 'inventadas' distinguem-se por estabelecer com ele uma continuidade muito artificial. As danças chamadas tradicionais do Festival Folclórico de Tefé, mais especificamente a Dança Africana, podem nos trazer uma reflexão a partir dos dados propostos por Eric Hobsbawm e Terence Ranger, quando os autores nos convidam a pensar sobre às chamadas "tradições inventadas". A pesquisa em pauta tem objetivos específicos e dentre eles, verificar como a dança se estabeleceu, além de analisar sua consolidação e até mesmo resistência, chegando a se tornar um símbolo tradicional entre os moradores:

Tradição inventada é um termo utilizado num sentido amplo, mas nunca indefinido. Inclui tanto as tradições realmente inventadas, construídas e formalmente institucionalizada, quanto as que surgiram de maneira mais difícil de localizar num perílodo limitado e determinado de tempo -às vezes coisas de poucos anos apenas - e se estabeleceram com enorme rapidez ${ }^{34}$.

A Dança Africana de Tefé, está categorizada como tradicional no contexto folclórico e cultural da cidade, como também os Grupos de dança Ciranda Tradição, Dança Afro-América e Dança Cunhã Poranga. Com relação a Dança Africana mais especificamente assim compreende D. Dora, uma das fundadoras da Dança Africana

Falando em tradição [...] E no meu entendimento a "Africana" é tradição porque tem aí...38 anos de existência, e vem se apresentando no folclore né [...] então ela é tradição para mim, neste ponto de vista,

\footnotetext{
${ }^{33}$ HOBSBAWM, Éric, RANGER, Terence. A Invenção das Tradições. São Paulo:Paz e Terra, 1997, p.09.

${ }^{34}$ HOBSBAWM, Éric, RANGER, Terence. A Invenção das Tradições. São Paulo:Paz e Terra, 1997, p.09.
} 
sobre a criação dela no folclore tefeense. Essa música, "Africana chegou ela é tradição...", foi uma das criações da D. Dulcina e se não me engano foi criada em 2007 ou 2008... e foi assim "vamos ter um grito de guerra!" e assim foi criada a saudação de entrada da "Africana"

Para a simpatizante da Dança Africana de Tefé e cantora da Ciranda Tradição Janiele Cavalcante, há um motivo e uma justificativa para as o termo "Danças Tradicionais":

No Festival Folclórico as danças que pertencem a categoria de "Danças Tradicionais" ....são aquelas que foram cridas originalmente aqui...até tentaram uma vez criar uma "Africana" em outro lugar, mas não foi possível, já que está registrada. O que não aconteceu com outras, nós temos o exemplo da Ciranda, que hoje é patrimônio cultural de Manacapuru, mas ela foi originalmente criada em Tefé, e foi levada para lá, isto gera uma insatisfação sim por parte de quem é tefeense [...] porque a Ciranda era nossa, ou seja, foi criada aqui pelo professor Antônio Felício... e por muito... muito tempo ela foi mantida. ${ }^{36}$

$\mathrm{Na}$ entrevista com a brincante, cuja família é ligada a várias danças em Tefé, e atualmente uma das cantoras da Ciranda Tradição, ela aponta claramente que a categoria de Danças Tradicionais está atrelada ao fato, das danças terem sido criadas ou (re)criadas originalmente em Tefé, ou seja, tem uma legitimidade ao serem criadas e elaboradas no município. Neste sentido podemos compreender que mesmo que a Dança Africana de Tefé -AM tenha sido constuída a partir de uma dança religiosa, ou ainda com passos vindos talvez do Gambá, ela tem uma originalidade, pois existirá uma apresentação da mesma forma que é estruturada aqui.

Para Hobsbawn e Terence (1997) as tradições inventadas podem ser percebidas em três categorias superpostas: a) as que se estabelecem ou simbolizam as coesões sociais ou as condições de admissão de um grupo ou de comunidades reais ou artificiais; b) as que se estabelecem ou legitimam instituições, status ou relações de autoridade; c) aquelas cujo propósito principal é a socialização, a inclusão de ideias, sistemas de valores e padrões de comportamento. (HOBSBAWN, TERENCE. 1997).

Utilizando-se ainda dos conceitos de Hobsbawn e Terence, sobre tradições inventadas poderíamos analisar que, estar classificada como uma dança "Tradicional" no Festival Folclórico em Tefé significa ter legitimidade, aceitação, status e de uma certa forma autoridade. Talvez por este motivo, as danças assim classificadas são justamente as que causam maior comoção nos expectadores e simpatizantes de forma geral

\footnotetext{
${ }^{35}$ Entrevista com D. Dora Marinho em novembro de 2018.

${ }^{36}$ Entrevista realizada com Janiele Cavalcante em março de 2019.
} 


\section{A RE(SIGNIFICAÇÃO) DA CULTURA E PRESENÇA NEGRA ATRAVÉS DA DANÇA AFRICANA DE TEFÉ-AM}

Para além do Festival Folclórico de Tefé, existem vários eventos como arraiais, quermesses e festas caipiras em que as danças de modo geral são convidadas a participarem e se apresentarem o ano inteiro. Entretanto, os meses de maio e novembro por serem respectivamente voltados para refletir sobre as causas negras como a luta pela abolição da escravatura e a consciência negra, as danças em que estão envolvidas as matrizes africanas são extremamente solicitadas.

Os brincantes da Dança Africana de Tefé inclusive são convidados a participar também de debates e discussões em instituições educacionais e também no espaço acadêmico, tornando-se porta-vozes e difusores destas causas. Apresentam também de uma forma mais resumida as músicas ritmadas pelos tambores e os principais elementos da dança com suas indumentárias características.

A questão de não haver ainda um despertar mais efetivo para as causas negras ou movimentos sociais identitários em Tefé fazem das danças, além de efetivamente ser referência de raízes culturais, são também referências sociais.

\section{CONSIDERAÇÕES FINAIS}

As percepções aqui apresentadas se constituíram através da coleta de entrevistas e dados documentais, realizadas com agentes sociais, que tem envolvimento ou são brincantes da Dança Africana, e revelaram a importância desta manifestação, seja ela no caráter folclórico ou artístico para a cultura e identidade deste grupo. Redimensionando estas percepções para o folclore tefeense, cujas outras manifestações de danças também fazem parte, foi possível constatar que este foi se dinamizando.

$\mathrm{Na}$ intenção de levar algo novo e diferente para o Festival Folclórico que estava no auge naquela época dos anos de 1980, de acordo com os dados coletados, há 40 anos atrás criou-se a Dança Africana. E independente de ser ou não um desdobramento da Dança do Gambá, do qual inclusive até hoje apresenta muitos de seus elementos, ela tornou-se representativa em vários âmbitos. Desta forma conclui-se que a dança não partiu de pessoas de vínculo com religiosidade e nem por pessoas de identidade negra, entretanto na percepção dos tefeenses ela representa e é considerada como uma referência, quando esta temática é abordada.

Neste sentido, podemos refletir que uma presença negra não está necessariamente veiculada a presença física do negro, mas ao fato de que as heranças e as influências 
culturais estão presentes, sejam elas na dança, na música, canto, lutas, vocabulário, religiosidade dentre outros. A Dança Africana reuniu vários elementos e mais a história, e vem ao longo dos anos sendo uma chama de uma cultura negra dentro do município de Tefé.

Data de submissão: $21 / 12 / 2021$

Data de aceite: 09/09/2021. 